\title{
Insulin Binding of Human and Porcine Monocomponent Insulin to Monocytes in Type 1 (Insulin-Dependent) Diabetic Patients and Control Subjects
}

\author{
R. Prager and G. Schernthaner \\ 2nd Department of Internal Medicine, University of Vienna, and Ludwig Boltzmann-Institute for Clinical Endocrinology. Vienna, Austria
}

\begin{abstract}
Summary. In the present study insulin binding properties of human semi-synthetic and porcine insulin were compared in Type 1 (insulin-dependent) diabetic patients treated from the onset of their disease either with human semi-synthetic insulin $(n=12)$ or porcine insulin $(n=12)$ and control subjects $(n=12)$. In all three groups, insulin binding to circulating monocytes revealed no difference between human semi-synthetic and porcine insulin (specific insulin binding at tracer concentration: $5.7 \pm 0.5 \%$ versus $5.4 \pm 0.5 \%$ in control subjects, $5.5 \pm 0.4 \%$ versus $5.4 \pm 0.4 \%$ in Type 1 diabetic patients
\end{abstract}

on porcine insulin, $5.3 \pm 0.4 \%$ versus $5.6 \pm 0.4 \%$ in Type 1 diabetic patients on human insulin). Treatment with human or porcine insulin did not have any significant influence on receptor binding properties of the two diabetic groups investigated. Absolute receptor number and affinity of both diabetic groups were within the range of healthy control subjects irrespective of treatment with human or porcine insulin.

Key words: Human insulin, insulin receptor binding, monocytes, porcine insulin, Type 1 diabetes.
It has been suggested that human insulin may offer advantages in insulin therapy of diabetes mellitus. Theoretical advantages of human insulin compared with porcine insulin may exist in terms of immunogenicity and/or biological potency [1, 2]. Furthermore, availability of biosynthetic human insulin may alleviate a possible shortage of animal pancreatic material. Biological differences in insulin preparations in different tissues could be caused by a change in binding to the cell surface receptor. Mutation of a single amino-acid in the insulin region thought to be involved in the binding of the receptor can cause marked impairment in binding to target tissues and subsequently in biological activity [3]. Bachmann et al. [4] reported that at lower insulin concentrations, binding of biosynthetic human insulin and purified human pancreatic insulin was significantly higher than that of porcine insulin. Other comparative binding studies of human and porcine insulin in a variety of human and animal tissues [5] revealed identical binding behaviour regarding affinity, association and dissociation kinetics and negative cooperativity.

In the present study, binding of semi-synthetic human insulin and porcine insulin to mononuclear leucocytes was compared among two groups of Type 1 (insulin-dependent) diabetic patients treated from the onset of their disease either with porcine or semi-synthetic human insulin and a group of control subjects.

\section{Patients and Methods}

\section{Patients}

Comparative insulin binding studies were performed in three groups of patients. Group 1 consisted of twelve healthy male adult volunteers (mean age: 26 years). All showed normal body weight and the hepatic and renal functions were within normal range. None took any drugs known to affect carbohydrate or insulin metabolism.

Insulin binding was compared in twelve Type 1 diabetic patients, who were treated from the onset of their disease with porcine insulin

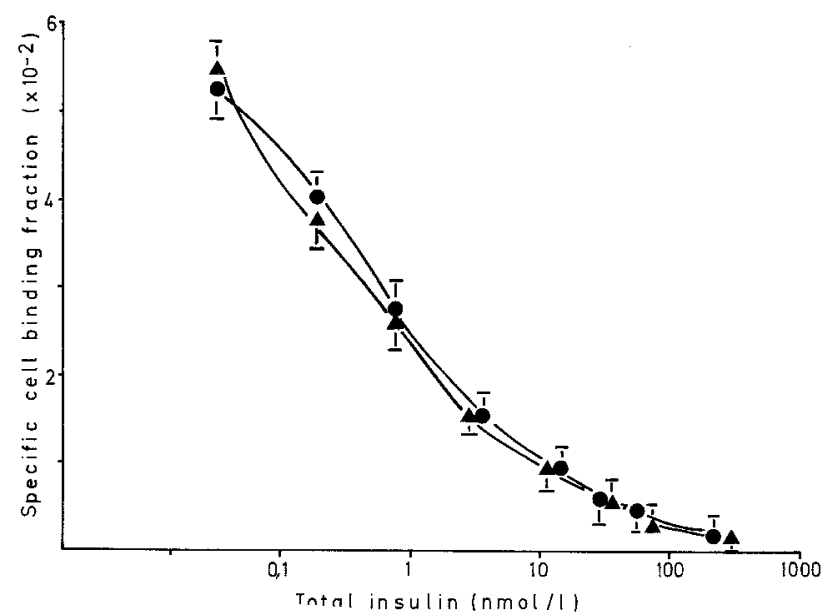

Fig. 1. Binding of human (-) and porcine $(-\Lambda)$ insulin in control subjects (mean \pm SEM) 
Table 1. Binding characteristics of human and porcine insulin to monocytes in control subjects, Type 1 diabetic patients treated with porcine insulin and Type 1 diabetic patients treated with human insulin

\begin{tabular}{|c|c|c|c|c|c|c|}
\hline & \multicolumn{2}{|c|}{ Control subjects $(n=12)$} & \multicolumn{2}{|c|}{$\begin{array}{l}\text { Porcine insulin-treated patients } \\
(n=12)\end{array}$} & \multicolumn{2}{|c|}{$\begin{array}{l}\text { Human insulin-treated patients } \\
(n=12)\end{array}$} \\
\hline & $R_{0}$ & $\begin{array}{l}\mathrm{K}_{\mathrm{E}} \\
\left(\mathrm{M}^{-1} / 10^{8}\right)\end{array}$ & $\mathbf{R}_{\mathrm{o}}$ & $\begin{array}{l}\mathrm{K}_{\mathrm{E}} \\
\left(\mathrm{M}^{\left.-1 / 10^{8}\right)}\right.\end{array}$ & $\mathrm{R}_{\mathrm{o}}$ & $\begin{array}{l}\mathrm{K}_{\mathrm{E}} \\
\left(\mathrm{M}^{-1} / 10^{8}\right)\end{array}$ \\
\hline Human insulin & $13100 \pm 2300$ & $4.50 \pm 0.31$ & $12900 \pm 2400$ & $4.43 \pm 0.48$ & $13900 \pm 2200$ & $4.42 \pm 0.35$ \\
\hline Porcine insulin & $12700 \pm 2100$ & $4.41 \pm 0.19$ & $13300 \pm 2600$ & $4.31 \pm 0.40$ & $14100 \pm 2300$ & $4.02 \pm 0.29$ \\
\hline
\end{tabular}

Results expressed as mean $\pm \mathrm{SEM} . \quad * \mathrm{R}_{\mathrm{o}}=$ number of binding sites per cell, $\mathrm{K}_{\mathrm{E}}=$ the limiting high affinity state was determined using the model of negative cooperativity

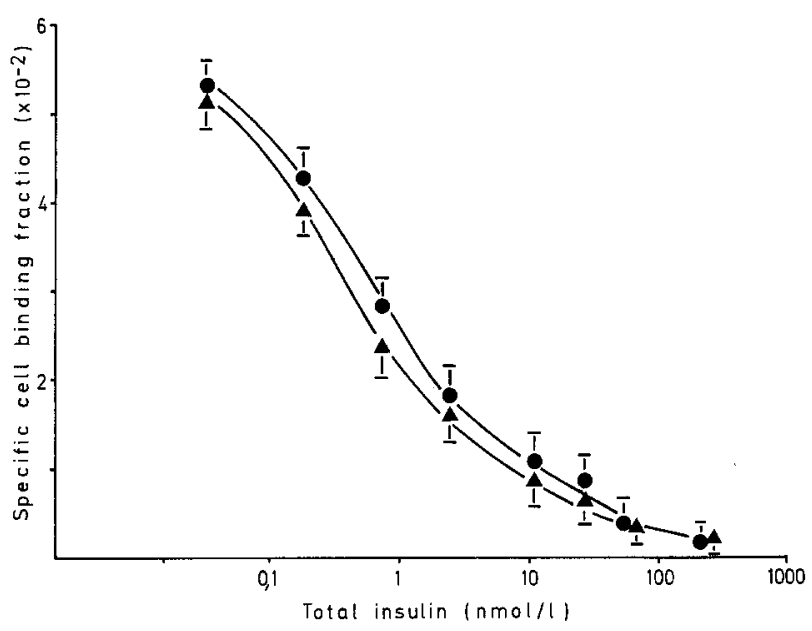

Fig. 2. Binding of human $(-\mathbf{O})$ and porcine $(\boldsymbol{\Lambda})$ insulin in Type 1 diabetic patients treated with porcine insulin (mean \pm SEM)

(group 2). All were within ideal body weight and their ages ranged from 17 to 36 years (mean $30 \pm 2$ years). The duration of diabetes was from 2 to 11 years.

Group 3 consisted of 12 Type 1 diabetic patients. Their age ranged from 16 to 32 years (mean age $23 \pm 1$ years). This patient group was treated with human insulin from the onset of their disease. The mean duration of diabetes in this group varied between 2-9 months. Body weight was within normal range.

At the time of investigation all the diabetic patients were in fairly good metabolic control (estimated by measurement of glycosylated haemoglobin: $8.9 \pm 0.9 \%$ in group 2 and $8.5 \pm 0.7 \%$ in group 3 ) and none presented with ketonuria. Both groups of diabetic patients fulfilled the classical criteria of insulin-dependent diabetes mellitus [6]. Endogenous insulin secretion, estimated by measurement of basal Cpeptide levels, was not detectable in any group 2 patients. In the diabetic patients treated with human insulin, basal C-peptide levels were below $0.2 \mathrm{pmol} / \mathrm{ml}$. The mean daily insulin requirement of the diabetic patients was $0.81 \pm 0.04 \mathrm{U} / \mathrm{kg}$ body weight in group 2 and $0.69 \pm$ $0.05 \mathrm{U} / \mathrm{kg}$ body weight in group 3 .

\section{Methods}

Cell binding studies: Insulin binding studies were carried out in the morning following an overnight fast. The last insulin dose before the studies was given in the previous evening. Blood $(120 \mathrm{ml})$ was drawn into tubes containing EDTA (dipotassium-salt). Mononuclear leucocytes were isolated by gradient centrifugation [7]. Insulin binding studies to mononuclear leucocytes were performed according to the method of Beck-Nielsen et al. [8]. The cells were washed twice and incubated in Hepes buffer $\left(100 \mathrm{mmol} / 1, \mathrm{pH} 7.8\right.$ at $\left.15^{\circ} \mathrm{C}\right)$ at a concentration of approximately $5 \times 10^{7} \mathrm{ml}$ for $100 \mathrm{~min}$ with ${ }^{125} \mathrm{I}$-human and ${ }^{125} \mathrm{I}$ porcine insulin at a concentration of $34 \mathrm{pmol} / 1(0.2 \mathrm{ng} / \mathrm{ml})$. The specific activity of the tracer was approximately $223 \mu \mathrm{Ci} / \mu \mathrm{g}$ and $225 \mu \mathrm{Ci} / \mu \mathrm{g}$, respectively. Native semi-synthetic or native porcine in-

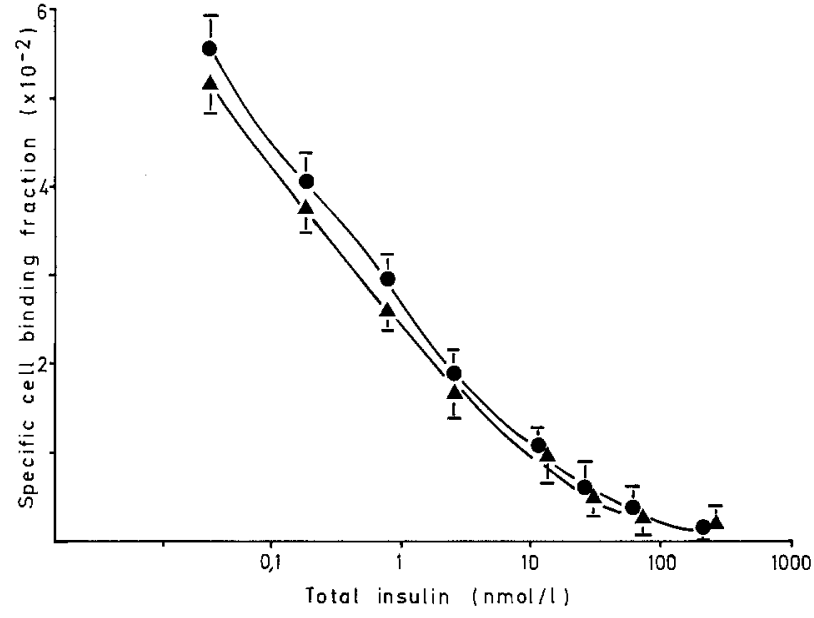

Fig. 3. Binding of human ( - ) and porcine $(-\mathbf{A})$ insulin in Type 1 diabetic patients treated with human insulin (mean \pm SEM)

sulin was added in increasing amounts to the incubation medium for the competition studies. Cell bound and free insulin were separated by centrifugation after the incubation period. The specific cell binding fraction was defined as total cell binding fraction minus non-specific cell binding, i.e. radioactivity which remained bound in the presence of an excess of native insulin $(10 \mu \mathrm{mol} / 1)$. This fraction averaged approximately $8 \%$ of the total binding. Monocytes were identified by alpha-naphthyl-acetyl-esterase staining [9] and specific cell binding fraction was adjusted to a standard concentration of monocytes of $1.0 \times 10^{7} \mathrm{ml}$ using the formula described by Beck-Nielsen et al. [8]. We could not observe any statistically significant difference between the numbers of monocytes in the two groups of the diabetic and control subjects.

Analysis of binding data: The results of the binding studies are presented as specific cell bound fraction, plotted as a function of total insulin concentration (competition curve). Binding data were further analyzed by the average affinity model of De Meyts and Roth [10].

Haemoglobin $\mathrm{A}_{1}$ was estimated by microcolumn chromatography [11] and immunoreactive C-peptide by radioimmunoassay [12].

Statistical methods: For comparison of human and porcine insulin bindings paired Student $t$-test was considered appropriate. Comparative binding studies between the two groups of diabetic and control subjects were performed by the unpaired t-test.

\section{Results}

The healthy control subjects showed no statistically significant difference between the binding of human and porcine insulin at any insulin concentrations tested (Fig. 1). Absolute receptor number and average affinity did not differ significantly between human and porcine insulin either (Table 1). 
The comparative binding data of human and porcine insulin in Type 1 diabetic patients treated from the onset of their disease with porcine insulin are summarized in Figure 2. In analogy to healthy control subjects, we found no significantly difference in insulin binding of human and porcine insulin to monocytes. There was also no difference between human and porcine insulin binding with respect to absolute receptor number or average affinity (Table 1 ).

In Type 1 diabetic patients treated from the onset of their disease with human semi-synthetic insulin (Fig. 3), we found no significant difference between human and porcine insulin with respect to insulin binding behaviour. None of the patients tested revealed any significant difference in insulin binding between porcine and human insulin to circulating monocytes. Average affinity and absolute receptor number were also identical between human and porcine insulin binding (Table 1).

Comparing the insulin binding properties of the Type 1 diabetic patients treated either with porcine or human insulin, we found no significant difference with respect to absolute receptor number and average affinity (Table 1). Furthermore, neither Type 1 diabetic patients treated with porcine nor patients with human insulin showed a significantly different binding behaviour compared with healthy subjects.

\section{Discussion}

In the present study insulin receptor behaviour was studied for the first time in newly diagnosed Type 1 diabetic patients treated from the onset of their disease with semi-synthetic human insulin. Insulin receptor number and insulin receptor affinity of these patients did not differ from that of control subjects, which is in accordance with previous reports of insulin binding studies in Type 1 diabetic patients with good metabolic control $[13,14]$. Furthermore, by comparing the binding of semi-synthetic human insulin and porcine insulin to isolated mononuclear leucocytes, identical binding properties in terms of receptor number and receptor affinity were found in both groups of diabetic and control subjects. These data are in contrast to recent findings by Bachman et al. [4], who reported significant differences of insulin binding at lower insulin concentrations. Two factors should be taken into consideration with respect to the observed findings of Bachmann et al. [4]. Erythrocytes were used as targets in this study. Recent comparative studies of insulin binding to monocytes and erythrocytes indicate that insulin receptor data determined in the erythrocyte model might not be an exact reflection of the insulin receptor status [15-17].

The observed different binding of porcine und human insulin in the study of Bachmann et al. [4] could be due to the great difference in the specific radioactivity of the labelled insulins used.

We conclude that the binding behaviour of semisynthetic human insulin and porcine insulin is completely identical. Furthermore, well-controlled Type 1 diabetic patients treated from the onset of their disease with semi-synthetic human insulin did not differ from those treated with porcine insulin with regard to their insulin receptor status. There seems to be no risk in changing from porcine to human insulin treatment considering peripheral insulin binding.

Acknowledgement. The authors thank Dr. L.G.Heding. Novo Research Institute, Copenhagen, Denmark for the generous supply of native and ${ }^{125}$ I-human semi-synthetic insulin.

\section{References}

1. Schernthaner G, Borkenstein M, Fink M, MayrWR, Menzel J, Schober E (1983) Immunogenicity of human insulin (Novo) or pork monocomponent insulin in HLA-DR-typed insulin-dependent diabetic individuals. Diabetes Care 6 (Suppl 1): 43-48

2. Home PD, Alberti KGMM (1982) Human insulin. Clin Endocrinol Metab 11: 453-483

3. Tager H, Given B, Baldwin D, Mako M, Markise J, Rubenstein A, Olefsky J, Kobayashi M, Koltermann O, Poncher R (1979) A structurally abnormal insulin causing human diabetes. Nature 281: $122-125$

4. Bachmann W, Sieger C, Lacher F, Lotz N (1981) Binding of biosynthetic human insulin to erythrocytes of normal and insulin-dependent diabetic subjects. Comparison with pork and human pancreatic insulin. Diabetes Care 4: 215-219

5. Keefer LM, Piron MA, De Meyts P (1981) Human insulin prepared by recombinant DNA techniques an native human insulin interact identically with insulin receptors. Proc Nat Acad Sci 78: 1391-1395

6. WHO-Expert Committee on Diabetes Mellitus (1980) WHO Technical Report No 646, WHO, Geneva

7. Boyum A (1968) Separation of leukocytes from blood and bone marrow. Scand J Lab Clin Invest (Suppl. 97) 22: 77-89

8. Beck Nielsen H, Pedersen O, Kragballe K, Sörensen NS (1977) The monocyte as a model for the study of insulin receptors in men. Diabetologia 13: 563-569

9. Yam LT, Li CY, Crosby WN (1971) Cytochemical identification of monocytes and granulocytes. Am J Clin Path 55: 283-286

10. De Meyts P, Roth J (1975) Cooperativity in ligand binding: A new graphic analysis. Biochem Biophys Res Commun 66: 1118-1126

11. Welch SG, Boucher BJ (1978) A microscale method for the measurements of hemoglobin $A_{/(a+b+c)}$ Diabetologia 14: 209-211

12. Heding LG (1975) Radioimmunological determination of human C-peptide in serum. Diabetologia 11: $541-548$

13. Fantus G, Ryan J, Gorden PH (1981) The insulin receptor in insulin-dependent diabetes mellitus: An in vivo and in vitro study. Metabolism 30: 510-517

14. Pedersen O, Beck Nielsen H, Heding L (1978) Insulin receptors on monocytes from patients with ketosis prone diabetes mellitus. Diabetes 27: 1098-1104

15. De Pirro R, Fusco A, Lauro R, Testa I, Ferreti G, Demartinis C (1980) Insulin receptors on monocytes and erythrocytes from obese patients. J Clin Endocrinol Metab 51: 1437-1439

16. Ward GM, Rees AR, Nylor BA, Turner RC (1981) The relationship of erythrocyte insulin receptors to the cell age and to monocyte insulin receptors. Clin Endocrin 14: 269-278

17. Prager R, Schernthaner G (1982) Comparison of insulin receptor binding of monocytes and erythrocytes in type II diabetes mellitus. Horm Metab Res 14: 561-563

Received: 20 November 1981

and in revised form: 13 June 1983

Dr. G. Schernthaner

2nd Department of Internal Medicine

University of Vienna

Garnisongasse 13

A-1090 Vienna

Austria 